\title{
Changes of Labor Education in the Past 70 Years Since the Founding of the People's Republic of China
}

\author{
Wuyun Gerile* \\ School of Education, Xizang Minzu University, Xianyang 712082, Shaanxi Province, China \\ *Corresponding author: Wuyun Gerile, 1945774935@qq.com
}

\begin{abstract}
Throughout the development of labor education in the past 70 years since the founding of the People's Republic of China, its development characteristics are different along with the varying stages of economic development. The development of labor education has an important relationship with the political system, economic policy, and cultural foundation. This article reviews the development process of labor education in the past 70 years since the founding of the People's Republic of China, analyzes the characteristics of labor education in each period, and proposes suggestions to promote the development of labor education in China, whereby the development of labor education should follow the basic rules of education development, grasp the characteristics of the times of labor education, and build a new system of labor education; adhere to people-oriented education and establish proper educational orientation; innovate the labor education system and build a labor education model with Chinese characteristics; improve the support and guarantee system of labor education and earnestly promote the implementation of labor education; enhance the internationalization of labor education and the international competitiveness of labor education.
\end{abstract}

Keywords: Labor education; Educational cooperation; Development stage; Changes

Publication date: November 2021; Online publication: November 30, 2021

\section{Introduction}

In recent years, labor education has gradually become a hot topic in China's education practice. From the origin of the history of labor education in China, its historical development and evolution contain the characteristics of productivity as well as scientific and technological advances, the improvement and innovation of the political and economic system, the inheritance and innovation of culture and education, the gradual deepening of the understanding of human nature, as well as the increasing liberation of human nature. After the founding of the People's Republic of China, from the perspective of the development process of labor education, the mandatory change in the characteristics of the education system, being largely affected by political factors, is highlighted. In order to promote a proper development of labor education, it is essential to accurately grasp the new connotation of labor education under the background of the new era, clarify the key points of labor education, and earnestly implement labor education.

\section{Labor education under the guidance of political equality}

The background of labor education after the founding of the People's Republic of China is reflected by the stable domestic political situation and various systems being in the stage of old and new innovation. Its fundamental goal is to gradually establish a perfect socialist system. At the same time, the people's awareness of democratic political rights has begun to increase. Due to the transformation of domestic 
contradictions, labor education faced the problem of establishment. After the founding of the People's Republic of China, the former Soviet Union's labor education faced the problem of learning and optimizing its system ${ }^{[1]}$. It is urgent to establish an appropriate labor education in consideration of the national conditions of the People's Republic of China and avoid blindly following the old labor education system before the founding as well as blindly advocating and copying the foreign labor education system. At this stage, the system advocates serving the proletariat and that education should be actively combined with production to serve both production and construction. Since 1963, the Ministry of Education has stipulated that students above the fourth grade of primary school should participate in half a month's labor every year. Since then, labor education courses and work study activities are focusing on students' participation in social productive labor. As a result, the labor education system in China has developed rapidly ${ }^{[2]}$. From 1966 to 1976, labor education gained an important status. The main mode of education at this stage was labor, in which all kinds of courses focused on labor. Intellectuals all over the country went to mountainous areas and countryside to work, advocating working first and then gaining cultural knowledge. Therefore, classroom learning was replaced by traditional manual labor.

The characteristics of the development of China's labor education in the early days of the founding of the People's Republic of China are discussed. In 1957, the educational policy determined by the state was "to enable the educated to develop in moral, intellectual, and physical education and become educated workers with socialist consciousness." In August of the same year, the State Council promulgated the Instructions on Educational Work, which determined that education serves proletariat politics and education should be combined with productive labor ${ }^{[3]}$. After the founding of the People's Republic of China, the state put forward the educational concept that theory should be combined with practice and labor education is an important way to put theory into practice. At this stage, there are many forms of labor education. For example, the thoughts of labor education have been integrated into the teaching of certain disciplines, and students' labor concepts are cultivated from many aspects; the summary and promotion of labor models as well as the stimulation of people's subjective consciousness in regard to loving labor; the regular practice of organizing practical physical activities, which engender students to feel the power of labor through forums and other forms, thus promoting the concept of independent labor. It has been put forward that labor education should be combined with production, the relationship between labor and production should be straightened out, the interaction between productivity and production relations should be emphasized, the development of social production should be better promoted, and intellectuals should be enlightened to realize the importance of labor education. Synchronous learning of labor education and cultural knowledge should be promoted, and all kinds of professional talents should be trained for socialist construction, so that labor education is no longer limited to the simple training of labor skills ${ }^{[4]}$.

\section{Labor education under the guidance of "rejuvenating the country through science and technology"}

From 1977 to the end of the 20th century, the Party Central Committee held the 3rd Plenary Session of the 11th Central Committee of the Chinese Communist Party, which clearly shifted the focus of China's development to economic construction along with the rectification of socialist education. Since then, labor education has been moving in a normal development path as exemplified by the gradual restoration of the college entrance examination system in solving the issue of talent gap under the socialist construction. In 1987, the State Education Commission issued the Syllabus of Labor Class in National Primary Schools, which incorporated labor course into main disciplines, stipulated that each grade should set up a labor course every week, implemented unified teaching materials and specialized teaching, as well as required students to master certain knowledge and skills in the labor course and cultivate their self-care ability and working habits. At this stage, labor education also began to break through the traditional way of thinking and actively integrated with socialist economic construction. Labor education began to enter the normal 
development stage again. In addition, under the influence that productivity determines production relations, the state began to vigorously develop science and technology education to promote economic construction with science and technology.

During the period from 1977 to 2011, labor education emphasized that science and technology is the primary productive force and took science and technology education as the core content of education. Labor education began to shift to an auxiliary position, while labor technology education and basic skills knowledge education were emphasized. Education should not only focus on physical education, but also on intellectual education and the cultivation of technical skills. Major colleges and universities are also experimenting with education and the teaching mode of combining teaching, scientific research, and production by actively combining labor education with economic construction as well as science and technology in accordance with the requirements of the Outline of China's Education Reform and Development in 1993, so as to actively serve the promotion of socialist modernization ${ }^{[5]}$. At the same time, labor education is no longer a simple labor behavior. Labor education is now linked with technical education, which assumes labor and technical education as having professional education content. Generally speaking, since the advent of the 21 st century, the development of science and technology education has become dominant, and labor education has gradually assumed an auxiliary role.

\section{Labor education under the guidance of national rejuvenation}

After entering the 21st century, China's economy has achieved rapid development. At the same time, the scope of reform and opening-up has been continuously expanded and deepened, while education has further strengthened international exchanges and cooperation, bringing new opportunities and challenges to China's education system. On the one hand, China has carried out a comprehensive pilot reform of basic education, that is the "new curriculum reform." This education reform comprehensively reflects and summarizes the past education system as well as proposes to establish and implement a socialist education system facing modernization and the future. Labor education is included in the practical curriculum as an auxiliary curriculum of modern education. On the other hand, the improvement of the level of education internationalization allows the education system in China to learn from various international thinking, and the collision of different educational cultures provides new thinking for the design of China's curriculum, which is conducive to promoting the reform and innovation of its education system, so as to promote the establishment of an education system suitable for China's national conditions.

Since 2012, the background of the development of labor education and the characteristics of the development are discussed below.

\subsection{Implementing the "integration of five education"}

The "integration of five education" refers to the integration of the development of labor education with the development of moral education, intellectual education, physical education, and aesthetic education. It is an innovation from the traditional model of "simultaneous development of five education," and it emphasizes that labor education should not only combine the characteristics of stage economic and social development, but also students' life practice, in order to realize the unity of knowledge and practice, thus inspiring students to develop the correct world outlook, outlook on life, and values. Labor education has become an important part of education in the new era. It is of great significance to cultivate new socialist builders and successors under the background of the new era.

\subsection{Establishing a labor education system}

Establishing a labor education system requires the system to be in line with the characteristics of the new 
era. The goal of the labor education system should be to cultivate the labor spirit of diligence, thrift, innovation, and dedication while having respect for labor achievements, basic labor skills to meet the needs of survival and development, as well as good labor habits. In the past, the labor education system was relatively scattered, its training objectives were relatively broad, and it was regarded as an auxiliary education. Under the background of the new era, the state has integrated labor education into other four educations. At the same time, its basic connotation, content, curriculum requirements, and assessment are enriched and refined, and its importance is more self-evident.

\subsection{Integrating labor education with international education ideas}

This integration refers to the inflow of international education ideas and models. It plays an important leading role in the reform of China's labor education. In foreign countries, labor education is reflected through practical courses, and it pays more attention to cultivating students' skills in using their brains and hands independently through practical courses. Practical education is the core feature of labor education. By reasonably setting up practical labor education courses, it would not only cultivate the participants' practical skills, but also exercise their brain capacity, which helps to promote the cultivation of innovative thinking.

\section{Suggestions and reflection on the development of labor education in China}

After reviewing and summarizing the development history of China's labor education, suggestions have been made from five aspects in order to promote a sound and rapid development of the labor education system.

\subsection{Labor education should follow the basic law of education development}

Labor education and basic education both have their own internal development law. One of the goals of labor education is to improve the labor ability of educated youth and promote the establishment of the correct concept of labor; however, its fundamental purpose is still to serve the socialist economic construction. Labor education is an important means to promote economic development. It should be promoted along the right track and should not be regarded as a tool or accessory of political struggle against its development law. The use of political power to interfere with the normal development of labor education should also be avoided. Other than that, labor education should conform to the participants' characteristics based on their age, emphasize on using both hands and brain, allow participants to experience the labor process in labor education, and enhance the practical effect of labor education. In addition, labor education should also adhere to local conditions while taking into consideration the regional natural, economic, and cultural characteristics, fully tap the labor education resources available in the region, as well as promote the optimal allocation of labor education resources.

\subsection{Labor education should adhere to the people-oriented concept}

The people-oriented concept emphasizes on human development because talents are the foundation of development. The same is true of labor education. Labor education takes people as the main body, promotes people through labor, and then integrates labor education with people, so as to finally promote the reform and innovation of labor education. Labor education attaches importance to people's labor needs. It does not only require people to work, but also drive the integration of labor with technology, cultivate people's labor skills, as well as encourage people to learn and optimize labor skills independently, so as to promote an allround development. It is necessary to make full use of science and technology as the primary productive force, actively promote labor education to adapt to the new changes of scientific and technological 
development, industrial reform, and social services, promote the "integration of five education," deepen the integration of industry and education, pay attention to the effectiveness of labor education, actively develop the methods of utilizing people's initiative to promote the improvement of labor education methods, as well as pay attention to the application of new knowledge, new technology, new process, and new methods, so as to improve students' skills in solving practical problems creatively.

\subsection{Labor education should promote reform and innovation}

In view of the differences in the corresponding contents of labor education in each development period in China, the role of labor education in different periods varies. Therefore, the content of labor education should also be adjusted according to the national conditions and social development needs at that specific time, so as to reflect and respect the characteristics of the times, keep pace with the times, explore, and innovate without being complacent. Taking into consideration of the current situation of the economic development in the new era and students' practical life, the government should actively explore a labor education model that not only meets the requirements of the current economic, cultural, and social system, but also adapts to the physical and mental development of students, so as to promote the establishment of a labor education model with Chinese characteristics while innovating the education system and mechanism. In addition, the reform and innovation of labor education should emphasize on comprehensiveness, such as the innovation of the basic connotation of labor education, its curriculum, evaluation system, and so on. Labor education must be innovative, so that it can truly and continuously adapt to the development needs of productivity and promote the sustainable development of labor education.

\subsection{Labor education should improve its support and security system}

Labor education should improve its support and security system. On the one hand, the government should improve the investment mechanism of labor education funds, raise funds through multiple channels and forms, as well as improve the supporting equipment and facilities for labor education. At the same time, the government can use social capital to encourage the society to participate in and support the development of labor education by formulating corresponding fiscal and tax policies in support of the development of labor education. On the other hand, the government should improve the professional talent training system of labor education; the government should not only encourage college students to apply for labor education courses, but also promote the reform of labor education mode in colleges and universities as well as improve the quality of labor education talents. Meanwhile, the government should integrate labor education into the content of teacher education assessment, encourage teachers' labor consciousness and labor concept, as well as actively promote the implementation of labor education. In addition, the government should improve the labor resource distribution system. It is necessary to actively increase and expand practice places that are suitable for labor education to meet the needs of schools in promoting labor education. Furthermore, in order to ensure the safe implementation of labor education, the government should establish and improve the safety guarantee system of labor education. Governments at all levels and their departments should encourage and help coordinate the active participation of schools, families, the society, and other subjects in the safety prevention and control of labor education. At the same time, schools are encouraged to buy labor education insurance for students and actively disperse the possible risks of labor education. Finally, the government should improve the emergency handling mechanism of labor education accidents, formulate detailed emergency prevention and control plans, as well as conduct regular drills to prevent those accidents from occurring. 


\subsection{Labor education should strengthen international cooperation and exchange}

The internationalization of education is an inevitable feature of the development of education to a certain extent. With the strengthening of China's comprehensive national power, its position in the world is becoming much more important. As a soft power, education cannot disregard its development. As far as labor education is concerned, it is essential to learn and draw lessons from international labor education thinking and build a new labor education concept that matches the characteristics of socialist education with Chinese characteristics. On the other hand, by actively inducing mature foreign practical curriculum models and learning their curriculum contents, methods, cases, and so on, which are beneficial to the country's education, would optimize the curriculum of labor education in China. By promoting the internationalization of labor education, it would help to promote the pace of reform and innovation of labor education in China, so as to raise the advantage of labor education in serving economic construction and social development.

\section{Disclosure statement}

The author declares that there is no conflict of interest.

\section{References}

[1] Chen T, 2015, The Historical Evolution and Reflection of Labor Education since the Founding of the People's Republic of China. Hainan Normal University.

[2] Zhou Q, 2019, Changes and Prospects of Labor Education Curriculum in Primary and Secondary Schools in China. Basic Education Curriculum, (05): 34-45.

[3] Li Y, 2019, Evolution and Enlightenment of Labor Education since the Founding of the People's Republic of China - Based on Thoughts on the Cultivation of New People in the Times. Modern Society, (22): 149-151.

[4] Zheng C, Wang S, 2019, Evolution, Era Connotation and Practice Path of Labor Education in China in the 70 Years since the Founding of the People's Republic of China. Contemporary Educational Science, (05): 14-18.

[5] Xu H, Ai Z, 2019, The Historical Process and Reflection of the Value Orientation of Labor Education in China during the 70 Years since the Founding of the People's Republic of China. Social Sciences in Guangxi, (11): 171-176. 